\title{
Community Currency Trading Method through Partial Transaction Intermediary Process
}

\author{
Kunihiko Kido Non-member (Hitachi, Ltd., kido@sdl.hitachi.co.jp) \\ Seiichi Hasegawa Non-member (Kuriyama Community Network, hase@iki2.jp) \\ Norihisa Komoda Member (Osaka University, komoda@ist.osaka-u.ac.jp)
}

Keywords : Community Currency, Coordinator, Multi-Agent Simulation

\section{Overview of Community Currency}

A community currency is local money that is issued by local government, NPO (Non-Profit Organization) to support social services. The purpose of introducing community currencies is to regenerate communities by fostering mutual aids among community members. In a community currency activity, matching between service users and service providers is important to improve the flow of service exchanges. However, there are local regions that can't adopt operations in which coordinators perform intermediary process because of restricted budget.

\section{Community Currency Trading Method through Partial Transaction Intermediary Process}

We propose community currency trading method through partial intermediary process (Fig.1), under operational environments without introducing coordinators all the time. In this method, coordinators perform coordination between service users and service providers during several months from the start point of transactions. After the period of coordination, participants spontaneously make transactions based on their trust area and a trust evaluation method in terms of the number of provided services and complaint information. The trust area represents the set of participants that can be reached within n- hops through their social network.

In the period of coordination, coordinators perform coordination based on complaint information.

After the period of coordination, a service user can select a service provider form their trust area. If the service user cannot find service providers within their trust area, they search for other trust areas and select a service provider form participants with the larger number of provided services.

After the transactions, if there is no complaint for the provided services, the edge between the service user and the service provider is generated in a social network.

\section{Simulation Results}

We evaluated the proposed method through multi-agent simulation. In this simulation, we expressed a social network among participants by using Watt's $\beta$ graph with a rewiring probability $\mathrm{p}$.

Each agent had the level of trust that is randomly assigned by Weibull distribution ( $\alpha$ : shape parameter). The level of trust represents the threshold of the number of transactions over which service users can trust service providers. The number of transaction of the proposed method was higher than that of the thod introducing the trust evaluation method only (Fig. 2).

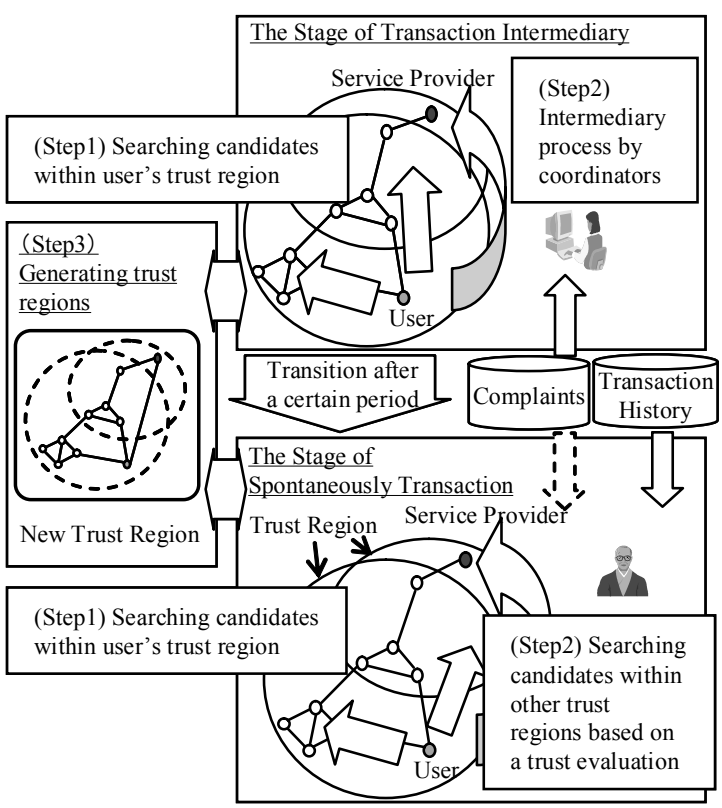

Fig. 1. Community currency trading method through partial transaction intermediary process

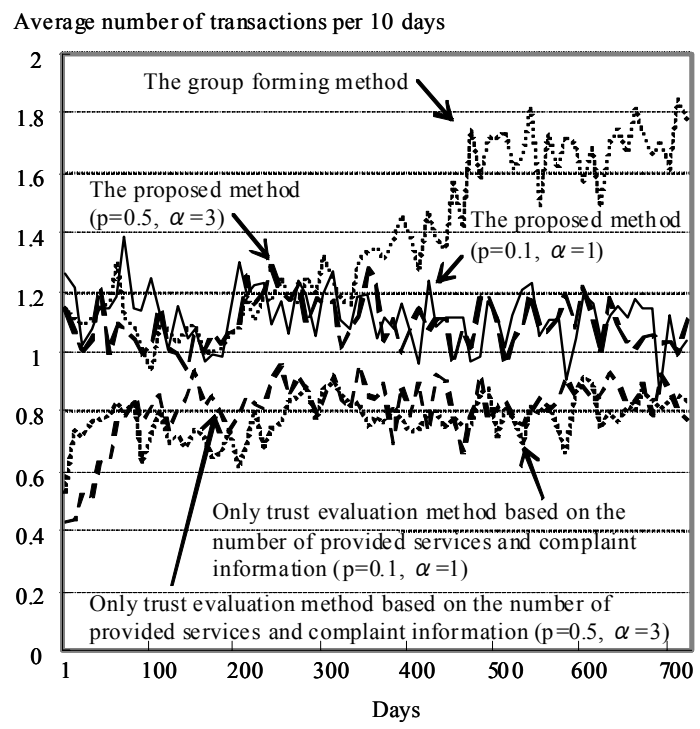

Fig. 2. Change in the number of transactions 


\title{
コーディネータを常設しない地域通貨取引における 部分的取引仲介による地域通貨運用方法の提案
}

\author{
非会員 木戸 邦彦* 非会員 長谷川 誓一** \\ 正 員 薦田 憲久***
}

\section{Community Currency Trading Method through Partial Transaction Intermediary Process}

Kunihiko Kido*, Non-member, Seiichi Hasegawa**, Non-member, Norihisa Komoda***, Member

A community currency is local money that is issued by local governments or Non-Profit Organization (NPO) to support social services. The purpose of introducing community currencies is to regenerate communities by fostering mutual aids among community members. In this paper, we propose a community currency trading method through partial intermediary process, under operational environments without introducing coordinators all the time. In this method, coordinators perform coordination between service users and service providers during several months from the start point of transactions. After the period of coordination, participants spontaneously make transactions based on their trust area and a trust evaluation method based on the number of provided services and complaint information. This method is especially effective to communities with close social networks and low trustworthiness. The proposed method is evaluated through multi-agent simulation.

キーワード : 地域通貨, コーディネータ, マルチエージェント・シミュレーション

Keywords : Community Currency, Coordinator, Multi-Agent Simulation

\section{1. はじめに}

地域通貨取引では，取引を活性化するためにはサービス 依頼者とサービス提供者のマッチングが重要であるが，こ れまで我々の研究グループではコーディネータによる仲介 方法(1) (3)を提案してきた。本方法は, 取引を集中管理し，コ ーディネータが信頼のおける提供候補者の中から，取引が 可能な限り成立するよう提供者を見つけ出す取引仲介を行 うため取引数が拡大するが，見ず知らずの相手からサービ ス提供を受ける機会も多くなることから，少なからずサー ビス利用者に取引相手に対する不安などの心理的負担をか ける。この対策として，取引関係にもとづき取引グループ を形成し，極力グループ内でサービス交換を行う運用をと

\footnotetext{
* (株) 日立製作所システム開発研究所

干224-0817 横浜市戸塚区吉田町 292 番地

Hitachi, Ltd., Systems Development Laboratory

292, Yosida-cho, Totsuka-ku, Yokohama 244-0817

** NPO 法人くりやまコミュニティネットワーク

干069-1511 北海道夕張郡栗山町中央 3 丁目 324 番地 1

Kuriyama Community Network.

324-1, 3-chome, Chuou, Kuriyama-cho, Yubari-gun, Hokkaido 069-1511

*** 大阪大学大学院情報科学研究科

干 565-0871 大阪府吹田市山田丘 2-1

Osaka University, Graduate School of Information Science and Technology.

2-1 Yamadaoka, Suita, Osaka 565-0871
}

ることで, この問題を軽減する方法を提案した(4)。しかしな がら, 各参加者が持つ知人関係を考慮せずに取引が進むた め，既存の交友関係が犠牲になるという課題が残る。また， 地域によってはコスト面等の制約からコーディネータを常 時雇用できず，取引仲介処理を行う運用を取らないケース も多い(5)。

本論文では, 上記コーディネータを常設せずに, 各参加 者が自律的に地域通貨取引を行う運用を取り上げる。コー ディネータによる取引仲介処理を行なわないケースでは, 参加者間の信頼感と各参加者の知人関係の状態が, 地域通 貨取引に影響を及ぼす。たとえば参加者間の信頼感が低い 場合には，サービス依頼者は信頼できる身近な参加者から サービス提供者を選ぶ傾向が強くなることが想定される。 この場合, 取引対象者が制限されることから, 取引の大幅 な拡大は期待できないが, 身近な参加者からサービスを受 けることができ安心感は高くなる。しかし, 各参加者が持 つ知人関係を超えて取引を拡大するとき, 取引相手の信頼 をどのように評価し, 安心感の高い取引を実現するかが課 題となる。

ネットオークション (6)では, 従来から参加者の信頼度を相 互評価する評判メカニズムを導入することで, この問題に 対処している。しかし, 互助精神の育成を目的とする地域 
通貨の場合，サービスに対する評価はなじまない。また活 動を開始して間もない取引初期では，取引数が少ないため 評価メカニズムが働かない。加えて, 取引初期時点での知 人関係が閉鎖的である場合，取引量は急には増えず，評価 メカニズムが機能するまでに時間がかかるという課題があ る。

本論文ではこの課題を解決するために，まず参加者の信 頼度の評価指標として取引提供量と苦情情報を採用する。 そして, 取引初期時点で知人関係が閉鎖的な場合に，取引 量を増やして評価メカニズムを早期に機能させるために, 取引の一定期間のみコーディネータが取引仲介処理を行な う地域通貨運用方法を提案する。これにより, 自律的な地 域通貨取引のメリットである，既存の交友関係をベースと した取引を活かしつつ, 取引数を一定レベルまで引き上げ, コーディネータがいなくなった後も, そのレベルを中・長 期的に維持できる状態を実現し, 取引数を確保することを 目指す。

そして，マルチエージェント・シミュレーションにより， 提案方法の有効性を確認する。特に, 取引初期時点で知人 関係が閉鎖的で，参加者間の信頼感が低い場合に提案方法 が有効であること，および，従来法である取引を集中管理 して取引仲介処理を行う方法に比べて, 既存の交友関係を ベースとした安心感が高い取引を可能にし，コーディネー タに関わるコストを削減しつつ, 取引数を一定レベルまで 拡大・維持できることを示す。

\section{2. 自律的な地域通貨取引における課題}

〈2·1〉地域通貨取引の仕組み 地域通貨活動の参加 者は，地域通貨支援システムに口座を開設し，氏名・住所・ 連絡手段（電話番号，電子メールアドレス等）および提供 可能なサービスと提供条件（曜日，時間，時間長など）を 登録する。

ここで各取引において，サービスを依頼する参加者をサ 一ビス依頼者, サービスを提供する参加者をサービス提供 者と呼ぶことにする。また, サービス依頼者にサービス提 供者を仲介する場合, その仲介者をコーディネータ(1) (3) と呼 ぶことにする。

まず, 参加者がサービスを依頼する時, サービス名・希 望日時・時間長などを地域通貨支援システムに登録する。 各サービス依頼に対して，サービス依頼者自ら，あるいは， コーディネータが, 登録サービス, 口座情報, 取引履歴に もとづき, 参加者の中から適切なサービス提供者を選出す る。コーディネータが仲介する場合には，メール等の手段 によりサービス提供者がサービス依頼者に紹介される。そ してサービス依頼者は, 選出されたサービス提供者に連絡 した後に, サービス提供を受け，サービス依頼者からサー ビス提供者に対して地域通貨の支払が行なわれる。このと き, 地域通貨の清算状況は口座データベースに記録される。

$\langle 2 \cdot 2\rangle$ 自律的な地域通貨取引の特徵 本論文では, 上 記地域通貨取引のうち, 参加者が自律的に取引を行う場合
を取り上げる。参加者による自律的な取引では, まず, 各 参加者の知人数や, 各参加者の知人関係にもとづき, 異な るサービスがどれだけ提供されるかに関する異質度が重要 である。さらに, 見ず知らずの相手に対してサービス依頼 を行う場合，心理的な障壁がある。これを参加者間の信頼 感のレベルと呼ぶ。また知人関係の連鎖により, どの範囲 の参加者まで信頼するかの, 信頼領域の広さの設定も重要 である。

このような観点から, 自律的な地域通貨取引に関する特 徵を明らかにする。まず，信頼感の観点で問題が少ない， 身近な参加者からサービス提供者を見つけ出せる機会が多 ければ取引数は伸びる。すなわち, 信頼領域内での異質度 が大きいほど取引活性化の観点からは好ましい。人的ネッ トワークの構造の観点から言えば, 取引初期時点で, 各参 加者がより多くの知人を持っていることが, 取引活性化の 観点で重要である。

一方，信頼領域外からサービス提供者を探す場合には， 参加者間の信頼感のレベルが取引の活性化に影響を及ぼ す。地域通貨を導入する地域の信頼感のレベルが低い場合 には, 顔見知りの範囲外の参加者との取引が増加しない。 したがって, 特に地域の信頼感のレベルが低い場合, 取引 を活性化するためには，取引相手の信頼性評価を支援する 仕組みが重要になる。

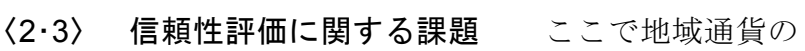
場合, ネットオークションで採用されているサービス内容 を相互評価する仕組みの導入は好ましくない。地域通貨の 導入目的は, サービス交換を通じた互助精神の育成にある。 5 段階評価など, サービス内容を直接的に評価する仕組みの 導入は, 互助精神育成の目的にそぐわない。また, 地域通 貨活動の参加者には, 小学生や高齢者などが含まれるが, このような社会的弱者にサービスレベルを評価させる運用 も無理がある。また，相互評価の仕組みを導入したとして も, 活動を開始して間もない取引初期では, 取引数が少な いため評価メカニズムが働きにくい。

一方, サービス内容の直接的な評価の代わりとして, 取 引提供量を利用することが考えられる。これは, 約束の時 間を厳守しないなど信頼に欠ける参加者は, サービス依頼 者から敬遠され取引提供量が伸びない。逆に，信頼のおけ る参加者の取引提供量は増大寸るためである。

しかしながら，取引提供量にもとづく信頼性評価におい ても, 取引がある程度まで進まないと機能しない。したが って, 特に取引初期時点では, 身近な参加者間での取引が 行われる傾向が強くなるが，各参加者の知人関係が閉鎖的 など人的ネットワークの構造が悪く, 信頼領域の異質度が 低いと取引数が伸びない。

以上から，参加者による自律的な地域通貨取引において は, 取引初期時点での異質度が低く, また, 参加者間の信 頼感が低い状態にあると取引が停滞する。また, 取引提供 量にもとづく信頼性評価が機能するまでに時間がかかると いう課題がある。取引を活性化するためには, この課題を 
改善する対策が必要となる。

\section{3. 部分的取引仲介による地域通貨運用方法}

〈3.1〉 提案方法の概要 取引初期時点の人的ネット ワークの状態を改善するために, 図 1 に示す部分的取引仲 介による地域通貨運用方法を提案する。本提案方法では, 取引初期の一定期間に取引仲介期間を設ける。取引仲介期 間後は, 参加者による自律的な地域通貨取引が行なわれる。

まず取引を開始する前に，各参加者は各自の知人関係を 地域通貨支援システムに登録する。この知人関係により人 的ネットワークと各参加者の信頼領域が定義される。

この知人関係に関する人的ネットワークは, 各参加者を ノード，参加者間の知人関係をノード間のエッジにより表 現することで構成される。この時, 参加者 $\mathrm{A}$ の信頼領域は, 上記人的ネットワークのエッジにもとづき, 参加者 $\mathrm{A} の$ の ードから $\mathrm{n}$ ホップ先の範囲内にあるノードに対応した参加 者の集合と定義する。そして信頼領域の広さは，nの大きさ を意味する。

提案方法の具体的な手順は次のとおりである。

ステップ 1 最初に, 取引仲介期間および取引仲介期間 以降のどちらも, 各参加者は各自の信頼領域から提供候補 者を探す。このとき, 各参加者の取引初期時点での信頼領 域の参加者をサービス提供者として優先する。もし提供候 補者が複数存在する場合, 地域通貨の所持額が最も少ない 者をサービス提供者として優先する。取引初期時点での信 頼領域内に提供候補者が存在しない場合には，下記ステッ プ 3 により, 取引が進むにつれ拡大寸るサービス依頼者の 信頼領域全体から提供候補者を探索し，もし提供候補者が 複数存在する場合, 地域通貨の所持額が最も少ない者をサ ービス提供者として優先する。

ステップ 2 各参加者が上記信頼領域内で提供候補者 を見つけ出すことが出来なかった場合, 取引仲介期間と取 引仲介期間以降で手順が異なる。

・取引仲介期間

コーディネータが取引仲介処理を行う。取引仲介処理で は，サービス依頼者のサービス条件にマッチした，苦情の ない提供候補者の中から，地域通貨の所持額が最も少ない 参加者をサービス提供者として選ぶ。

- 取引仲介期間以降

各参加者が取引提供量と苦情情報による信頼性評価にも とづき, 信頼領域外から提供候補者を探し, 地域通貨の所 持額が最も少ない参加者をサービス提供者として選ぶ。

ステップ 3 取引終了後に, コーディネータあるいは参 加者自身が，地域通貨支援システムが提供する人的ネット ワーク拡大処理機能を使用し, 取引関係のあったサービス 依頼者とサービス提供者の間でエッジを形成する。取引が 繰り返されることで人的ネットワークが拡大し，各参加者 の信頼領域は拡大する。ただし，提供されたサービスに対 して不満がある場合には，このエッジは形成しないものと する。

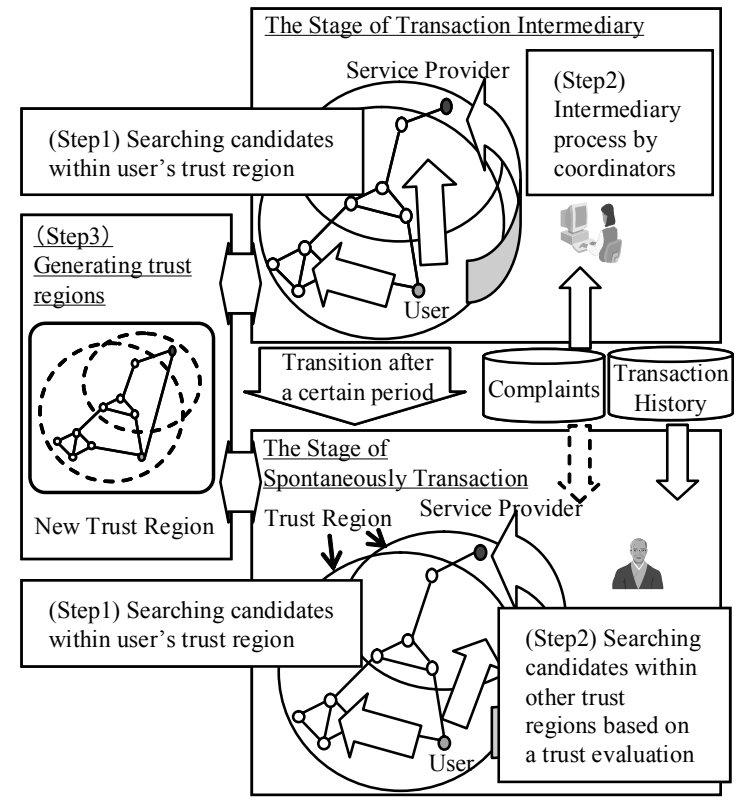

図 1 部分的取引仲介による地域通貨運用方法

Fig. 1. Community currency trading method through partial intermediary process.

上記，取引仲介期間を設けることで，取引提供量による 信頼性評価を機能させる取引量まで，早期に引き上げるこ とが可能となる。また, 信頼領域の異質度が低い場合でも, 取引仲介により取引初期時点の人的ネットワークが拡大す るため, 取引範囲が拡大する。

〈3·2〉苦情に関する処理と取引提供量の関係 提供 サービスに関する苦情処理のために, サービス利用者が取 引終了後に苦情に関する情報を登録できる機能を, 地域通 貨支援システムに設ける。苦情に関する情報を, 参加者全 員に公開することはプライバシー上の問題があるため, 通 常はコーディネータにのみ閲覧を許可する。ただし, 苦情 が頻繁に寄せられる参加者が存在する場合, その参加者が 所属する信頼領域内の参加者に対しては, その苦情情報を 公開する運用をとる。

取引仲介期間において，参加者が信頼領域内で提供者を 見つけ出せない場合には, コーディネータが取引仲介処理 を行なうが，このとき上記苦情に関する情報にもとづき， 信頼の面で不安のある参加者をサービス依頼者に紹介しな い運用をとる。また全取引期間を通じ, 各参加者が自律的 に地域通貨の取引を行なう場面では，極端に苦情の多い参 加者はその苦情情報が信頼領域内に公開されるため, 少な くとも苦情の多い参加者への依頼が抑制される。以上から, 信頼のおけない参加者の取引は抑制され，逆に信頼のおけ る参加者の取引提供量は次第に増加することになる。

取引仲介期間以降は, 参加者が信頼領域外からサービス 提供者を探す場合，コーディネータでないので苦情に関す る情報は閲覧できない。しかし，取引仲介期間を経た後は， 信頼のおける参加者は取引提供量の拡大が期待できるた め, 取引提供量を取引相手の信頼度の評価指標として利用 


\section{することができる。}

〈3.3〉 取引相手の信頼性評価の考え方 本提案方法 における取引相手の信頼性の評価は，信頼領域内の取引と 信頼領域外の取引において考え方が異なる。まず，信頼領 域内の取引においては，知人関係にもとづく人的ネットワ 一クをベースにサービス提供者を探し出すことで取引相手 を信頼する。特に, 取引後のサービス依頼者とサービス提 供者によるエッジ形成に際して, 提供サービスに対して不 満がある場合，このサービス提供者とのエッジは形成しな い。これにより，人的ネットワークおよびこの人的ネット ワークをベースとした信頼領域の質が維持される。

一方, 信頼領域外の取引において, 取引仲介期間では, コーディネータが苦情情報にもとづき取引仲介処理を行な うことを担保に，取引相手を信頼することになる。また， 取引後に形成するサービス依頼者とサービス提供者とのエ ッジについて，信頼領域外の信頼面で不安のあるサービス 提供者とのエッジは形成されないことから，信頼領域内の 取引と同様に，人的ネットワークおよびこの人的ネットワ ークをベースとした信頼領域の質が維持される。最後に, 取引仲介期間以降の信頼領域外の取引においては, 取引提 供量が多い取引相手を信頼することになる。

\section{4. 地域通貨取引のマルチェージェントモデルと 人的ネットワークのグラフ表現}

本章では, 3 章の提案方法をシミュレーション評価する準 備として, 地域通貨取引のマルチェージェントモデルと人 的ネットワークに関するグラフ表現について説明する。

\section{〈4-1〉地域通貨取引のマルチェージェントモデル}

地域通貨活動の事例によれば，地域通貨活動全体の枠組 みは, 地域通貨取引を行う場と, 地域通貨活動に伴う参加 者間の相互作用による社会学習の場からなると考えること ができる。既出論文 ${ }^{(3)}$ にならい,この 2 つの場の働きをマル チエージェントモデルにて表現する。まず, 各参加者をエ ージェント $A_{i}(i=1 \cdots n)$ として表現し，コミュニティ活動 への積極性を表す共感度 $E_{i}(i=1 \cdots n)$ を持つとする。また エージェントは, 地域通貨の取引参加数 $T_{i}(i=1 \cdots n)$ を記 憶している。ここで取引参加数 $T_{i}$ は, サービスの利用量と サービスの提供量に関する一定期間内の累積和とする。

地域通貨取引の場では, 各エージェントが利用確率 $P_{i}(i=$ $1 \cdots n)$ にもとづき取引を行う。この利用確率 $P_{i}(i=1 \cdots n)$ は, 共感度 $E_{i}$ の影響を受ける。同様に, 各エージェントが サービスの提供依頼がなされたとき，その依頼を受諾する 受諾確率 $Q_{i}(i=1 \cdots n)$ も共感度 $\mathrm{E}_{\mathrm{i}}$ の影響を受ける。

ここで図 2 の「社会学習 (1)」では, 各エージェントの 共感度 $E_{i}$ の平均や取引参加数平均に関する情報が参加者に 伝わる。このとき各参加者は，上記情報から各自の規範に もとづき, 今後の活動水準を決める共感度を変化させ取引 量を調節する。具体的には, 共感度 $E_{i}$ を増減させ, 地域通 貨サービスの利用確率 $P_{i}$ と受諾確率 $Q_{i}$ を変化させる。この 共感度 $E_{i}$ の増減の仕方を決める規範としての行動変容ルー

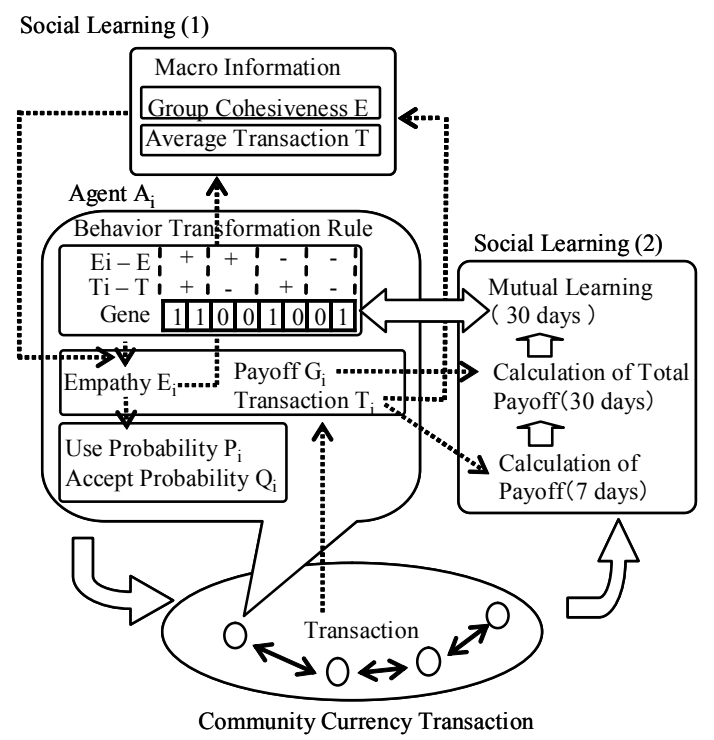

図 2 地域通貨取引のマルチエージェントモデル

Fig. 2. Multi-agent model of community currency transactions.

ルは, エージェントごとに個性を持たせ, 次のとおり 8 ビ ットの遺伝子で表現する。

まず, 周辺参加者の共感度の平均と各自の共感度との差, 周辺参加者の取引参加数の平均と各自の取引参加数との差 について，その符号の組み合わせは正・正，正・負，負・ 正, 負・負の 4 通りがある。そして，4 通りの組み合わせご とに, 「共感度を増加させる」「減少させる」「現状維持」の 3 つの振る舞いがある。これをビット列で表現するに際し て, 在間の方法(7)にならい, 8 ビットを 2 ビットずつに分解 し，それぞれが上記 4 通りのケースの振る舞いを規定する ものとする。たとえば, 共感度の平均と自分の共感度の差 が正で, 取引参加数の平均と自分の取引参加数の差が正の 場合は, 8 ビットの最上位 2 ビットに着目し，11 の参加者 は積極的な参加者を表現し共感度に 1 加える。また, 最上 位 2 ビットが 00 の参加者は消極的な参加者を表現し共感度 から 1 差し引く。また, 01 または 10 の参加者は, 中立的な 参加者を表現し共感度は現状を維持する。同様に, 共感度 の平均と自分の共感度の差と取引参加数の平均と自分の取 引参加数の差が, 正・負の場合は次の 2 ビット, 負・正の 場合はその次の 2 ビット, 負・負の場合は最下位 2 ビット に着目する。

最後に, 図 2 の「社会学習 (2)」は所定の利得関数にも とづき実施される。

〈4・2〉提案方法での社会学習 提案方法は, 各参加 者の信頼領域にもとづき地域通貨取引を行うため, 図 2 の 「社会学習 (1)」はこの信頼領域にて行うのが自然である。 寸なわち, 信頼領域内の共感度の平均や取引参加数平均に 関する情報は, 人的ネットワークを介して信頼領域内を伝 播する。そして, この情報と各参加者が所有する行動変容 ルールにもとづき, 共感度が定期的に書き換わるものとす る。また提案方法において, 図 2 の社会学習 (2)」は, 取引経験者を学習の場に参加させるよう, 運営団体が促す 
運用を行うものとする ${ }^{(3)}$

〈4·3〉人的ネットワークのグラフ表現 提案方法の 有効性をシミュレーション評価するためには，人的ネット ワークの構造が地域通貨取引に与える影響を調べる必要が

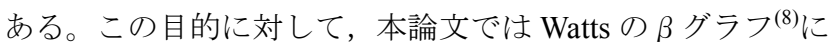
より人的ネットワークを表現する。Watts ラフのノード数と位数を固定した正則グラフに対し, 各ノ ードのエッジを確率 $p$ にもとづきリワイアリングする。確 率 $p$ を 0 から 1 に変化させることで, 正則グラフからラン ダムグラフへと連続的に変化させることができる。

ここで, 上記グラフ構造の変化と異質度の関係について 説明する。まず $p$ が 0 に近づくと, 正則グラフに近づくた めグラフの最小パス長が大きくなり ${ }^{(8)}$, 少ないホップ数で到 達できる参加者が限られるため, 提供されるサービス数に 限界が生じ異質度は下がる。したがって，各参加者の信頼 領域内では, 取引相手が見つからず取引不成立となる可能 性が高まる。逆に $p$ が 1 に近くなるにつれ，グラフの最小 パス長が小さくなり ${ }^{(8)}$, 少ないホップ数で到達できる参加者 数が増大寸るため, 信頼領域内で提供されるサービス数が 拡大することで異質度が向上する。

\section{5. シミュレーション評価}

〈5・1〉人的ネットワークと信頼感の取引への影響 提 案方法の比較対象として，まず，部分的取引仲介を行わず 取引提供量と苦情情報による信頼性評価のみ導入した運用 方法について，人的ネットワークと信頼感の影響を調べる。 この時, マルチェージェント・シミュレーションの利得関 数および各種パラメータは既出論文 ${ }^{(3)}$ と同じとした。この各 種パラメータは，北海道栗山町の第 2 次エコマネー流通実 験のデータにもとづいており，553 名のエージェントが 475 のサービス項目について取引を行う。また，ランダムに $10 \%$ の参加者を選び信頼できない参加者とした。そして，信頼 できない参加者との取引においては, サービス依頼者が 80\%の確率で苦情を登録するとした。ボランティアサービ スの場合，参加者はサービスに対して高い質を求めている わけではない。したがって，苦情が発生するのは，極端に サービス内容が悪い場合である。この場合，当該サービス 提供者の活動に対する基本姿勢に，そもそも問題があるこ とが想定されるため, このような参加者がサービス提供者 になった場合には，苦情が高い確率で発生するとした。

また, 各参加者の信頼領域を 3 ホップ先の範囲とした。 地域通貨は，新しい人と人の結びつきを拡大することが目 的にある。したがって, 各参加者は身近な知人よりも少し 遠めの参加者との取引を試みるので，若干大きめのホップ 数を設定した。そして，信頼のできない参加者の苦情が 3 件に達した時点で，その参加者が所属する信頼領域内にそ の苦情情報を公開する運用を採用した。

ここで，人的ネットワークと信頼感の影響を調べるため に，553ノード，位数 4 の正則グラフをベースとした Watts の $\beta$ グラフに対して, 確率 $p$ と参加者間の信頼感のレベル

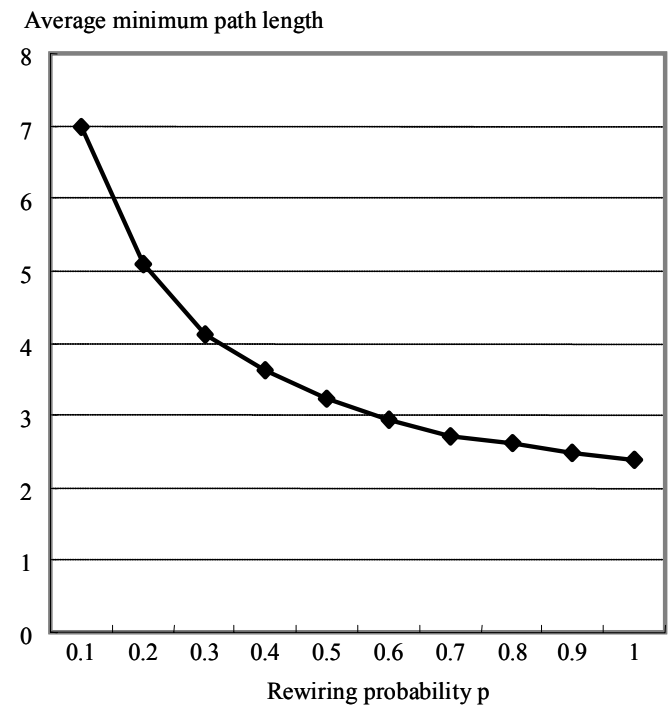

図 $3 \beta$ グラフの最小パス長の平均

Fig. 3. Average minimum path length for $\beta$ graph.

を変化させ取引の推移を調べる。

図 3 は, 確率 $p$ を 0.1 から 1.0 まで 0.1 ずつ変化させた各 $\beta$ グラフについて，任意の 2 ノード間の最小パス長に関す る平均值をプロットしたものである。確率 $p$ が増加するに したがい, 最小パス長の平均值は急速に減少するが, $p=0.5$ からこの減少は緩やかになる。したがって， $\beta$ グラフの確 率 $p$ については, $p=0.1$ を各参加者の信頼領域が平均的に狭 く異質度が低い例とし,$p=0.5$ を各参加者の信頼領域が平均 的に広く異質度が高い例として採用した。

ここで各参加者に，提供候補者の取引提供量がどのレベ ルであれば相手を信頼するかの閾值を持たせる。たとえば， 取引への心理的障壁が低い参加者は, 1 回以上の取引経験者 を信頼する。逆に心理的障壁が高い参加者は, 3 回以上の取 引経験者でないと信頼しないことになる。この取引提供量 の受容のようなタイプのアンケート調査においては, 平均 值等の推定にワイブル分布による生存分析を行うことが多 い。そこで各参加者への閾值の割り振りは, ワイブル分布 にもとづき乱数を生成し, その整数部分に 1 を加えた数值 を割り付けた。極端に大きい閾值を持つ参加者は, 活動そ のものに参加しないことが想定できるため, 闇值のばらつ きは小さいと考えられる。よって, ワイブル分布の形状母 数 $\mathrm{m}$ は, 分布が対称的な形状で裙野が短い 3 に設定した。 また，尺度母数 $\alpha$ を 1 3 とした。各 $\alpha=1 \sim 3$ のときの平均 值は，それぞれ $0.3 ， 1.2 ， 2.1$ 近辺の值となる。すなわち $\alpha$ が小さいほど, 上記閾值の平均值が下がることから, 参加 者間の信頼感のレベルが高いことになる。

図 4 は, $p=0.1$ と $p=0.5$ の場合の, 20 回試行による 10 日 単位での取引平均の推移である。 $p=0.1$ の場合, 取引初期時 点において急速に取引数が伸びるものの, 取引平均が 0.7〜 0.8 回付近で飽和する。一方, $p=0.5$ の場合も, 取引初期時 点において急速に取引数が伸び, 最終的に取引平均が $0.8 \sim$ 0.9 回付近のレベルまで達する。しかし， $\alpha=3$ の場合, 取引 
Average number of transactions per 10 days

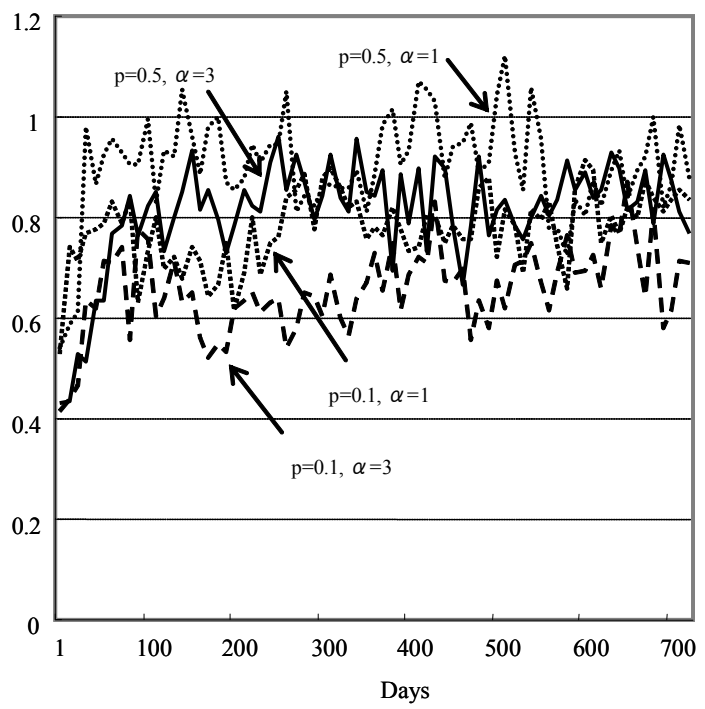

図 4 人的ネットワークと信頼感の地域通貨取引への影響

Fig. 4. The influence of social network and trust for community currency transactions.

平均が 0.9 回付近に達するまで, 300 日程度かかってしまう。 $p=0.1$ の場合, 各参加者の信頼領域の異質度が低いので, 信頼領域内の取引数に限界があり, 取引数が伸びないため に取引提供量による信頼性評価のメカニズムが十分に働か ない。したがって, $p=0.5$ の場合に比べると取引数のレベル がさがる。特に， $\alpha=3$ のように参加者間の信頼感が低いと， 取引初期時点での信頼領域外への取引が期待できないた め, $\alpha=1$ に比べると取引数のレベルが下がってしまう。

〈5-2〉提案方法との比較 図 5 , 図 6 は,取引仲介期 間を 50 日，100日，200日に変化させた場合の提案方法と 取引提供量と苦情情報による信頼性評価のみを導入した運 用方法について, 20 回試行による 10 日単位での取引平均の 推移を示したものである。取引量の落ち込みに着目寸ると， 取引仲介期間を 200 日に設定するのが良いことがわかる。

提案方法は, 取引初期時点から取引平均が $1.1 \sim 1.2$ 回に 達し，全取引期間を通じてこのレベルを維持できる。そし て, 取引提供量と苦情情報による信頼性評価のみ導入した 運用方法と比べて, 高い水準で取引が安定し, 全期間を通 じて $1.2 \sim 1.3$ 倍程度, 取引平均が改善する。図 5 , 図 6 では, 異質度は大きい $(p=0.5)$ が信頼感が低い $(\alpha=3)$ 場合と, 異質度は小さい $(p=0.1)$ が信頼感が高い $(\alpha=1)$ 場合とを 比較したが，異質度も信頼感も低い状態であれば提案方法 はさらに有効性を発揮する。なお，信頼領域がホップ数 2 の場合に同様なシミュレーションを行うと，取引仲介期間 を 350 日程度に設定すると, ホップ数 3 と同様なレベルま で取引数を引き上げることができた。したがって，500 名程 度の地域通貨活動の場合は，取引仲介期間を最長でも 1 年 に設定すれば十分であることがわかる。

次に, 取引の信頼性を評価するために, 取引に占める苦 情件数の割合の推移を調べた (図 7 参照)。提案方法の苦情

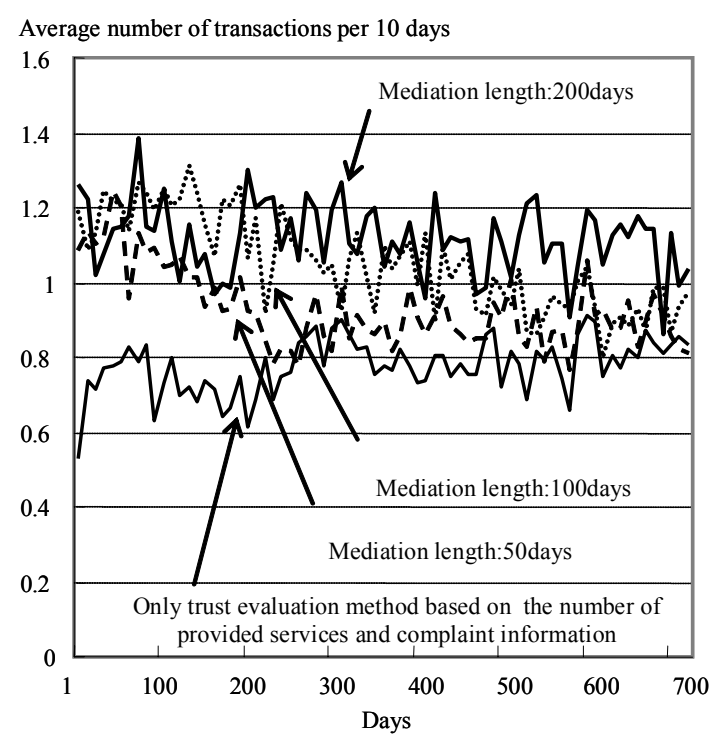

図 5 取引数の推移 $(p=0.1, \quad \alpha=1)$

Fig. 5. Change in the number of transactions $(p=0.1, \alpha=1)$.

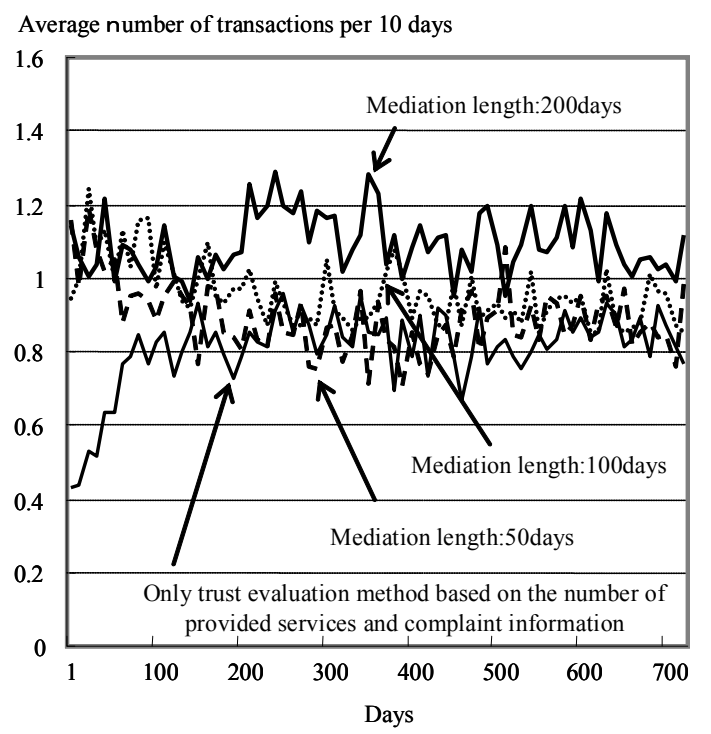

図 6 取引数の推移 $(p=0.5, \quad \alpha=3)$

Fig. 6. Change in the number of transactions $(p=0.5, \alpha=3)$.

件数の割合は，取引提供量と苦情情報による信頼性評価の み導入した運用方法と比べて改善する。これは, 取引仲介 期間において，コーディネータが苦情情報にもとづき取引 仲介処理を行なうため, 信頼の面で不安のある参加者が信 頼領域に取り込まれにくくなるためである。

以上から，提案方法は取引の信頼性を維持しつつ，取引 初期時点から取引平均のレベルを改善できる。

$\langle 5 \cdot 3\rangle$ 従来法との比較 取引の拡大と知人関係を心゙ 一スとした取引の安心感確保にはトレードオフの関倸があ り, 従来法である取引グループ形成などの集中管理型の取 引仲介方法 ${ }^{(4)}$ と, 本論文の提案方法のどちらかが一方的に優 れるということはない。 


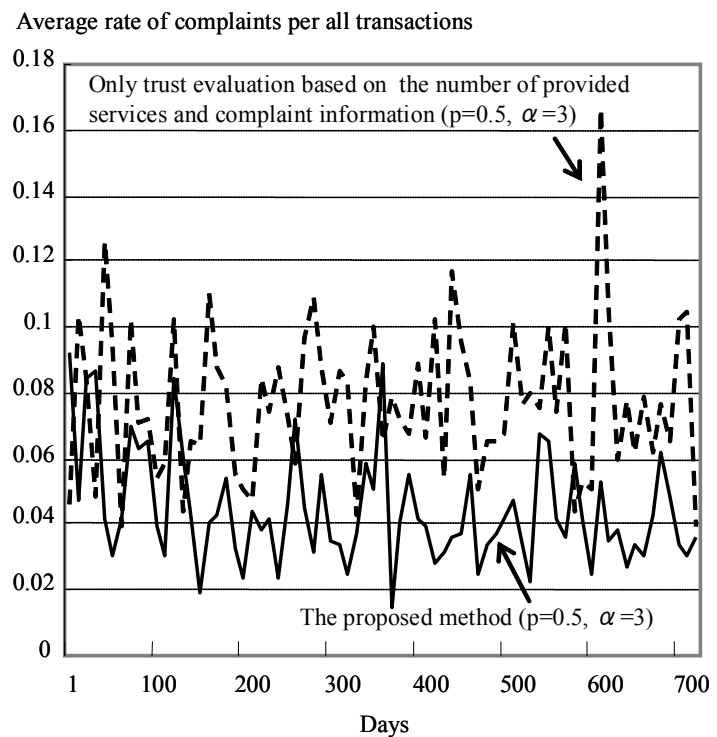

図 7 苦情件数の割合の推移

Fig. 7. Change in the rate of complaints for provided services.

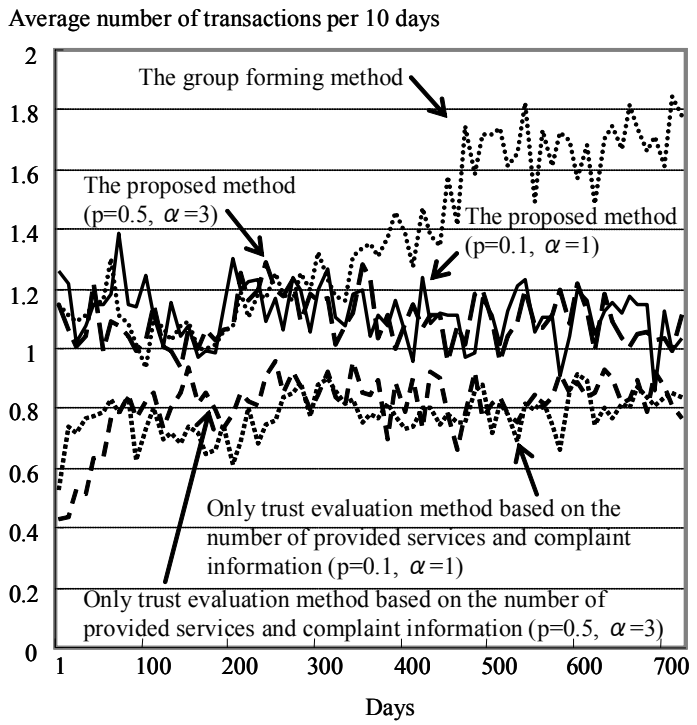

図 8 取引数の推移

Fig. 8. Change in the number of transactions.

取引グループ形成の方法では，全体の取引を俯瞰するな かで，コーディネータが取引仲介および社会学習の仲介を 行うために取引数は継続的に拡大寸る。一方，本論文にお ける提案方法は, 取引仲介期間後に取引を各参加者の自律 性に任すため, 取引数の継続的な拡大は期待できない（図 8 参照)。

一方, 取引の安心感に関しては，全取引に占める取引初 期時点の知人からサービス提供を受ける割合について比較 する。まず，取引日 $t$ における全取引を $T(t)$ とする。そして 各取引 $t r \in T(t)$ のサービス提供者に関して，サービス依頼者 の取引開始時点における信頼領域一の所属関係を表現する 関数を $\delta(t r)$ にて表現する。また, $|T(t)|$ |取引日 $t$ における

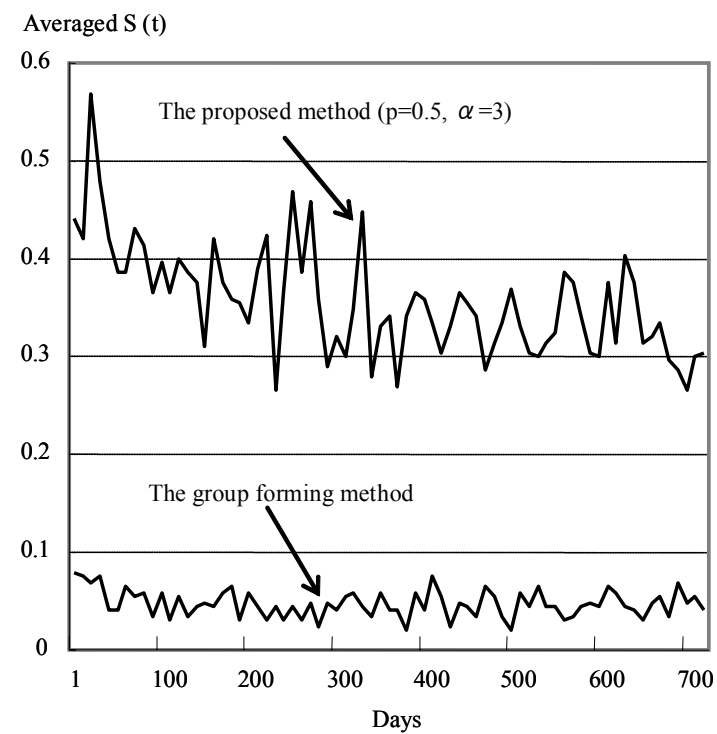

図 9 知人同士での取引推移

Fig. 9. Change in the number of transactions among acquaintances.

取引総数とする。このとき次式は, 取引日 $t$ における, 全取 引に占める取引初期時点の知人からサービス提供を受けた 取引の割合を表す。

$$
\begin{gathered}
S(t)=\left(\sum \delta(t r)\right) /|T(t)| \\
\operatorname{tr} \in T(t)
\end{gathered}
$$

ここで, 提案方法と従来法について, 式(1)の $\mathrm{S}(\mathrm{t})$ の推移を 比較する。図 9 は, 従来法と提案方法について, 20 回試行 による 10 日単位での $S(t)$ の平均值の推移である。従来法は 全期間を通じて $0.05 \sim 0.09$ であり, 参加者が持っている既 存の知人関係が取引に考慮されていないことがわかる。一 方, 提案方法は $0.3 \sim 0.5$ であり, 従来法に比べると大幅に 改善する。すなわち提案方法は, 全取引の $30 \%$ 程度はサー ビス利用者の知人からサービスを受けることが可能であ り, 安心感の面では提案方法が優れていると言える。

\section{6. まとめ}

本論文は，コーディネータを常設せず，各参加者が自律 的に地域通貨取引を行う運用を取り上げた。そして, 取引 の一定期間は取引仲介処理を行うものの, それ以後は各参 加者の拡大された人的ネットワークと, 取引提供量と苦情 情報による信頼性評価をベースに, 各参加者が自律的に地 域通貨取引を行う運用方法を提案した。

マルチェージェント・シミュレーションによる評価結果 によれば，取引初期時点での人的ネットワークや信頼感が 悪い状態において, 提案方法が特に有効であることがわか った。そして，取引を集中管理してコーディネータが取引 仲介処理を行う方法に比べて, 安心感が高い取引を可能に し，コーディネータに関わるコストを削減しつつ, 取引数 を一定レベルまで拡大できることがわかった。 
なお，コーディネータを常設し取引仲介を行う運用にお いても，自律的に取引を行いたいという参加者がいる可能 性がある。この場合, 本論文における提案方法とコーディ ネータによる取引仲介方法を組み合わせた, ハイブリッド な運用も考えられる。この場合，コーディネータに関わる コストが削減できないデメリットがあるが，取引の安心感 の向上が期待できるメリットもある。この組み合わせを含 め, 今後, 実フィールドでの実証実験にて検証を行ってい $<。$

(平成 17 年 9 月 7 日受付, 平成 18 年 1 月 16 日再受付)

\section{文献}

(1) K. Kido, J. Yamaguchi, T. Sekozawa, K. Haruna, and H. Toyosima : "Development and Evaluation of Regional Community Regeneration Supported Systems by Introducing Community Currencies", IPSJ-GN, 2002-GN-42, pp.31-36 (2002-1) (in Japanese)

木戸邦彦・山口 淳・瀬古沢照治・春名公一・豊島 久:「地域貨幣 導入による地域コミュニティ創生支援システムの開発と評価」, 情報 処理学研報, 2002-GN-42, pp.31-36 (2002-1)

(2) K. Kido, K. Haruna, S. Hasegawa, and T. Kato : "Trustable Coordinator Supported Value-Exchange Systems of Voluntary Services in Communities", Proc. The 46th Meeting of The Int. Soc. for the Syst. Sciences (ISSS), 2002-078, CD-ROM (2002-8)

( 3 ) K. Kido, S. Hasegawa, and N. Komoda : "Community Currency Trading Method and Evaluations by Multi-Agent Simulation", IEE Japan, Inf. Syst., IS-05-25, pp.41-45 (2005-6) (in Japanese) 木戸邦彦・長谷川誓一・薦田憲久：「地域通貨の仲介方式とマルチエ ージェント・シミュレーションによる評価」, 電気学会情報システム 研資，IS-05-25, pp.41-45 (2005-6)

(4) K. Kido, S. Hasegawa, and N. Komoda : "Enhanced Community Currency Trading Through Transaction Group Formation", Proc. Int. Conference on Computational Intelligence for Modelling Control and Automation (CIMCA'2005) (2005-11)

（5）新しい経済活動をともなう地域経済の活性化に関する研究会:「新し い経済活動をともなう地域経済の活性化に関する研究会」報告書, （財）地域活性化センター (2004-3)

(6) 根来龍之・木村 誠: ネットビジネスの経営戦略一知識交換とバリ ユーチェーン，日科技連 (1999)
( 7 ) K. Zaima : "An Agent-Based Simulation on Decision Process toward Uniformity of Community", Bulletin of the Senshu Univ. Res. Institute of Commerce, Vol.34, No.7, pp.1-17 (2003)

在間敬子: “コミュニティ形成のエージェントベースシミュレーショ ン一豊島産業廃棄物不法投棄事件を題材に一”，専修大学商学研究 所報, 34, 7,pp.1-17 (2003)

(8) D J. Watts : Small Worlds: The Dynamics of Networks Between Order and Randomness, Princeton Univ. Press (2003)

木 戸 邦 彦 (非会員) 1965 年生。1991 年 3 月東京理科大

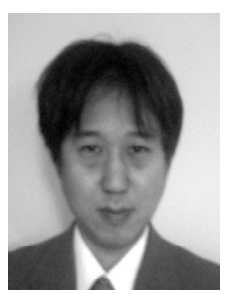
学大学院理学研究科数学専攻修了。同年(株)日 立製作所入社。システム開発研究所勤務。電子 自治体，地域情報化等の研究開発に従事。IEEE などの会員。

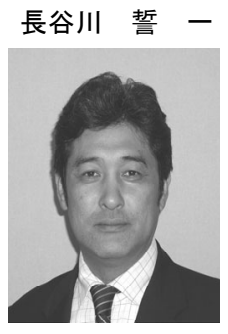

(非会員) 1956 年生。1979 年 3 月淑徳大学福 祉学部卒業。同年栗山赤十字病院に勤務。2003 年 4 月から「NPO 法人くりやまコミュニティネ ットワーク」の理事長も勤務。

薦 田 憲 久 (正員) 1950 年生。1974 年 3 月大阪大学大学

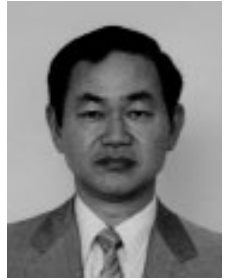
院工学研究科電気工学専攻修士課程修了。同年 （株）日立製作所入社。システム開発研究所勤 務。1991 年 4 月大阪大学工学部情報システム工 学科助教。現在, 同大学大学院情報科学研究科 マルチメディア工学専攻教授。工博。情報シス テムの研究に従事。電気学会 2000 年度進歩賞 などを受賞。IEEEなどの会員。 